\title{
Oncogene ABL1
}

National Cancer Institute

\section{Source}

National Cancer Institute. Oncogene ABL1. NCI Thesaurus. Code C17397.

Human v-abl Abelson murine leukemia viral oncogene homolog 1 (ABL1) gene, located at 9q34.1, encodes proto-oncogene tyrosine-protein kinase ABL1 protein. Alternative splicing of this gene produces two protein isoforms. A t $(9 ; 22)$ translocation, resulting in the fusion of the BCR and ABL1 genes, has been detected in many cases of chronic myelogeneous leukemia.. This BCR-ABL fusion gene is also present in acute myeloid leukemia and acute lymphoblastic leukemia. 